haka ni kuma na ke so in kashe ka bisa kokarinka, ba sa'ad da ka ke ba wani makami a hannunka ba. Yanzu ko kana so, ko ba ka so, sai ka d auki mashin nan ka taso mini, sa'an nan ni ko in tsire ka.'

\title{
Third International Congress on Phonetic Sciences.
}

This Congress, which has become the leading international centre of phonetic studies, was held at Ghent during July, and was attended by no less than 280 members from many countries. African languages and their phonetics were well represented, mainly at a special Session on Anthropology. Dr. Ida C. Ward spoke on 'Tone in West African Languages', T. E. Pardoe on 'African 'Tonal Patterns extant in present-day Afro-American Speech ', A. Basset on 'Aires phonétiques homogènes et non-homogènes' (in Berber dialects), and D. Westermann on the writing of African languages. Particular interest was shown in the click sounds in South African languages, three papers dealing with the phenomenon, viz. I. van Ginneken, 'Les Clics, les consonnes et les voyelles dans l'histoire de l'humanité '; R. Stopa, 'Die Schnalzlaute', and P. de V. Pienaar, 'Click Formation and Distribution'. While it will be generally admitted that clicks are an archaic form of human speech-sounds, van Ginneken went so far as to maintain that all languages originally used clicks only, till gradually out of them other sounds developed and finally the clicks were dropped in most languages, and to-day exist only as relics. This is an interesting hypothesis, but it will hardly be possible to prove it.

An important by-product of the Congress was the foundation of the International Society of Phonetic Sciences. The President of the new Society is Professor Daniel Jones of London, and its Journal will be the Archiv für vergleichende Phonetik published in Berlin by D. Westermann and E. Zwirner.

Royal African Society.

THE Rev. E. W. Smith, D.D., has been appointed Editor of the Journal of the Royal African Society, following the retirement of Mr. R. Nicholson, C.M.G., who had filled the dual position of Secretary and Editor of the Journal. Dr. Smith, who is a member of the Council of this Institute and is well known to readers of Africa, was for many years engaged in missionary work in Basutoland and Northern Rhodesia. He is an ex-President of the Royal Anthropological Institute and has been Editorial Superintendent of the British and Foreign Bible Society since 1933.

Mr. S. F. Deck has been appointed Secretary to the Society. He also has wide African experience and from 1920 to 1925 held the appointment of Principal Inspector of Labour, in which capacity he travelled widely in 